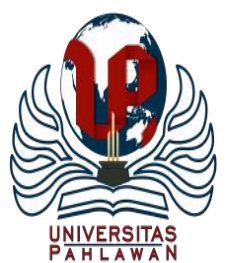

Edukatif : Jurnal Ilmu Pendidikan Volume 3 Nomor 5 Tahun 2021 Halm 3113 - 3122

EDUKATIF: JURNAL ILMU PENDIDIKAN

Research \& Learning in Education

https://edukatif.org/index.php/edukatif/index

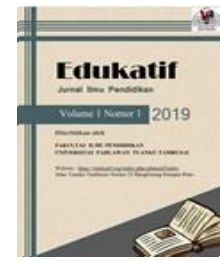

\title{
Self-Efficacy Guru terhadap Dinamika Pembelajaran Online di Masa Pandemi Covid-19
}

\author{
Muhammad Shofiyyul Muna ${ }^{1 凶}$, Nurul Khotimah², Yeni Jamilatuz Zuhaira ${ }^{3}$
}

UIN Sunan Kalijaga Yogyakarta, Indonesia ${ }^{1,2,3}$

E-mail : $\underline{\text { shofiymuhammad@gmail.com }}{ }^{1}, \underline{\text { nurulkhotimahmo@ @mail.com }}^{2}$, yenijamila23@ gmail.com ${ }^{3}$

\begin{abstract}
Abstrak
Tujuan penelitian untuk mengungkap dan mendeskripsikan bagaimana self-efficacy guru terhadap dinamika pembelajaran online di masa pandemi Covid-19. Penelitian dilakukan di SD Negeri Trimulyo II, Desa Trimulyo, Kecamatan Guntur, Kabupaten Demak. Metodologi yang digunakan yaitu metode kualitatif dengan pendekatan fenomenologi. Teknik pengumpulan data melalui wawancara kepada seluruh Guru SD Negeri Trimulyo II. Hasil penelitian menunjukkan bahwa self-efficacy Guru pada SD Negeri Trimulyo II secara keseluruhan berada pada level sedang dan positif. Begitu juga dengan ketiga dimensi self-efficacy yaitu; dimensi magnitude, guru terlihat berada pada level sedang dan positif yang menggambarkan bahwa guru akan berupaya melakukan tugas yang dianggap dapat dilaksanakan dan menghindari situasi serta perilaku yang di luar batas kemampuannya. Kemudian dimensi generality, guru berada pada level sedang dan negatif, keyakinan guru untuk menyelesaikan tugas yang berbeda-beda berada di level sedang. Selanjutnya, dimensi strength, memiliki kesamaan yang berada di level sedang dan positif, bahwa guru memiliki pengharapan yang cukup kuat dan mantap. Sehingga guru terdorong cukup gigih dalam berupaya untuk menyelesaikan tugas. Dengan demikian, dari hasil penelitian ini ditemukan bahwa atmosfer sekolah yang ternyata dapat menumbuhkan dan memberikan spirit bagi guru serta siswa dalam melaksanakan proses pembelajaran online selama pandemi.
\end{abstract}

Kata Kunci: Self-Efficacy, Pembelajaran Online, Pandemi Covid-19.

\begin{abstract}
The purpose of this study is to elucidate the self-efficacy of teachers in the dynamics of online learning during the Covid-19 pandemic. Investigations were conducted at SD Negeri Trimulyo II, Trimulyo, Guntur, Demak. The methodology used a qualitative method with a phenomenological approach. The data collection method by interviews with all teachers SD Negeri Trimulyo II. As a result, the self-efficacy of SD Negeri Trimulyo II teachers as a whole was relatively positive. Similarly, the three dimensions of self-efficacy, the dimension of size, show that teachers are performing tasks that are considered to be performed by regular teachers and are trying to overcome situations or behaviors that are beyond their ability. And it seems to be on a positive level. Here are the general aspects, teachers are at medium and negative levels, and teachers' confidence that they can complete different tasks is at normal levels. There is also a positive level of similarity in terms of intensity, but teachers have very strong and stable expectations. Therefore, teachers work very patiently in carrying out their work. The results of this study suggest that the atmosphere in schools is growing and provide a spirit to teachers and students when conducting online learning courses during the pandemic.
\end{abstract}

Keywords: Self-Efficacy, Online Learning, Covid-19 pandemic.

Copyright (c) 2021 Muhammad Shofiyyul Muna, Nurul Khotimah, Yeni Jamilatuz Zuhaira $\triangle$ Corresponding author:

Email : shofiymuhammad@gmail.com

DOI : https://doi.org/10.31004/edukatif.v3i5.754

ISSN 2656-8063 (Media Cetak)

ISSN 2656-8071 (Media Online)

Edukatif : Jurnal Ilmu Pendidikan Vol 3 No 5 Tahun 2021 p-ISSN 2656-8063 e-ISSN 2656-8071 
3114 Self-Efficacy Guru terhadap Dinamika Pembelajaran Online di Masa Pandemi Covid-19 - Muhammad Shofiyyul Muna, Nurul Khotimah, Yeni Jamilatuz Zuhaira

DOI: https://doi.org/10.31004/edukatif.v3i5.754

\section{PENDAHULUAN}

Pada awal 2020 terjadi wabah berupa pandemi yang dinamakan virus Covid-19. Menurut data WHO, sifat virus yang cenderung sangat mudah menyebar dan menular, serta cukup mematikan membuat semua negara di dunia berusaha menekan laju penyebarannya (Sukesih et al., 2020). Pandemi Covid-19 yang datang dengan cepat dan tiba-tiba, memberikan dampak secara cepat diberbagai belahan negara. Sesuatu yang belum pernah di prediksi sebelumnya, membuat geger budaya serta menyebabkan suatu perubahan pada seluruh dimensi kehidupan tiap manusia termasuk di negara Indonesia. Perubahan yang cepat dan pengaruh signifikan yang dirasakan negara mapun masyarakat terhadap berbagai sektor-sektor bidang. Mulai dari sektor ekonomi, sosio-ekonomi, politik, budaya, tak terkecuali menyentuh pada bidang pendidikan kita di Indonesia.

Oleh sebab itu, Bapak Joko Widodo selaku Presiden RI menginstruksikan untuk melakukan kegiatan serta aktivitas dari rumah yang disebut WFH atau work from home. Pemberlakuan WFH ini tidak hanya dilakukan oleh dunia usaha melainkan juga terhadap dunia pendidikan sehingga berdampak pada pola pendidikan yang selama ini dilaksanakan (Christianto, 2020). Dalam masa pandemi ini menjadikan tantangan tersendiri bagi elemen-elemen pendidikan terkhusus untuk kepala sekolah, guru, dan siswa untuk menghadapi role model pembelajaran yang efektif dan terjangkau, bahkan sampai melibatkan orang tua di lingkup keluarga. Regulasi dalam Pendidikan seketika harus mengikuti arus perubahan baik segi tatanan maupun tuntutan terhadap penerapan sistem pembelajaran berbaasis online di berbagai lembaga pendidikan., kegiatan belajar mengajar adalah suatu hal yang pokok, salah satu komponen utama adalah guru (Aini, 2018). Tugas guru selain sebagai figur pencerah yang dapat menata perlaku peserta didik (Mansyur, 2020a), ia (guru) juga dituntut untuk mendeskripsikan permasalahan baru yang dihadapi dalam pembelajaran online (Unik Hanifah Salsabila et al., 2021) dan seharusnya pula menuntaskan kurikulum pembelajaran, kini pendidik harus membuat pembelajaran jarak jauh (PJJ) yang menyenangkan dan memastikan kegiatan pembelajaran agar tetap efektif, inovatif serta berjalan secara maksimal, meskipun dari jarak jauh. Seakan memberikan gambaran bahwa dunia pendidikan kita ini "mampu" menghadapi perubahan secara cepat dikemudian hari.

Namun sayangnya, pembelajaran yang awalnya secara klasikal atau tatap muka secara langsung, setelah adanya pandemi Covid-19 model pembelajaran harus diganti dengan pembelajaran jarak jauh atau Online Learning dengan berbagai model media online yang ada sebagai alternatif. Selain itu, dalam rangka menghadapi tantangan, para pendidik juga harus bersiap diri untuk merespons situasi - kondisi pada masa pandemi, melalui sikap dan tindakan sekaligus untuk menerapkan suasana belajar dengan perpaduan hal-hal yang baru serta mencari solusi untuk pemenuhan hak dari pendidikannya.

Berkaitan dengan dinamika pembelajaran online, peneliti dalam wawancaranya kepada salah satu guru di sekolah dasar. Ia menyatakan bahwa kendala-kendala itu menjadi catatan penting terhadap dunia Pendidikan. Pasalnya, pendidik harus mengejar target pembelajaran online secara cepat. Padahal, secara teknis dan sistem pendidikan kita belum ada respon siap. Selama ini pembelajaran online hanya sebagai konsep dan perangkat teknis, belum sebagai cara berpikir, yaitu sebagai paradigma pembelajaran. Pembelajaran online bukan metode untuk mengubah role pembelajaran, bukan pula membebani siswa dengan tugas yang bertumpuk setiap hari. Melaikan hakikat dari Pembelajaran online ialah mendorong pelaku Pendidikan menjadi inovatif-kreatif dalam pemanfaatan technology digital yang sudah canggih, dengan cara mengakses sebanyak mungkin sumber ilmu pengetahuan, mampu menghasilkan karya, mengasah wawasan dan pembentukan karakter yang di nilai secara kompleks di era globalisasi saat ini.

Sejalan dengan hal itu, peneliti juga memberikan wawancara kepada Kepala Sekolah, yang menyatakan bahwasanya pembelajaran online seharusnya dapat dijadikan sebagai kesempatan mentransformasi pendidikan kita. Transformasi tersebut meliputi mindset, ekosistem, budaya atau lingkungan belajar sampai sistem pedagogi. Adapun langkah yang dapat menjadi acuan dalam perbaikan sistem pendidikan kita, khususnya pada pembelajaran online, yaitu Pembelajaran yang eksploratif bukan abstrak sehingga mampu berpikir kritis 
3115 Self-Efficacy Guru terhadap Dinamika Pembelajaran Online di Masa Pandemi Covid-19 - Muhammad Shofiyyul Muna, Nurul Khotimah, Yeni Jamilatuz Zuhaira

DOI: https://doi.org/10.31004/edukatif.v3i5.754

(Critical Thinking). Generasi milenial, membutuhkan pendidikan yang personalised yaitu memberikan otonomi dalam belajar, bukan hanya menyeragamkan. Mereka butuh pengajaran pendampingan bukan ceramah klasikal, karena hanya cenderung monoton dan tidak mengembangkan kuatan dan ketrampilan dalam belajar.

Selanjutnya, dalam wawancara yang dilakukan peneliti kepada Guru BK di sekolah tersebut. Yang menjelaskan bahwa pentingnya tahapan psikologi, baik bagi Guru maupun siswa, yaitu; disruptive innovation, tujuannya agar situasi disrupsi tidak dimaknai sebagai ancaman melainkan suatu peluang untuk menciptakan iklim kreativitas atau pemikiran yang beragam. Setidaknya pelaku pendidikan harus di bekali dengan pembangunan mental antara lain; Kecerdasan emosional, Percaya diri, Berani mengatakan tidak, Adaptasi dengan perubahan, Tidak menjadikan kesalahan sebagai beban, dan lain-lain.

Menurut hemat penulis, menyatakan bahwa dimensi Pendidikan seyogyanya harus bersikap fleksibel dan terus menerus beradaptasi. Kita dapat ketahui, bahwa ketakutan akan perubahan role model pembelajan saat ini, hanya akan menimbulkan rasa kehawatiran dan cemas yang berlebihan. Maka dari itu, hanya dengan menerima perubahanlah serta mampu menemukan inovasi, kreatifitas, serta berpikir positif, untuk dapat menjadi lebih baik. Karena tiap-tiap masyarakat, khususnya bagi elemen pendidikan harus selalu bersikap lapang dada agar tidak menimbulkan kebingungan dalam menghadapi pandemi sekarang ini.

Dengan demikian, berdasarkan penjelasan yang telah dipaparkan, maka penulis mencoba mengaitkan prihal dinamika pembelajran online di masa pandemi Covid-19 dengan Self efficacy guru khusunya pada tingkat Sekolah Dasar atau sederajat. Self-efficacy adalah keyakinan seseorang tentang kemampuannya untuk sukses dalam situasi tertentu. Yang meliputi; bagaimana orang berfikir, berbuat, dan merasa. Karena dalam situasi-kondisi seperti ini. Pendidikan sangat mempengaruhi Self-efficacy yaitu yang dilaluinya dalam mengembangkan kompetensi menuju profesionalitasnya. Apa yang di peroleh dalam dunia pendidikan dapat menjadi modal keyakinannya dalam melakukan tugas yang sesuai dengan latar belakang pendidikannya tersebut. Jika pendidikan yang diterimanya dapat menumbuhkan self efficacy yang tinggi, maka ia akan menjadi inovator dan akan mudah mempengaruhi lingkungan pekerjaannya dengan prilaku yang meyakinkan. Namun, jika pendidikan yang dilaluinya tersebut tidak mampu memberikan self efficacy yang memadai maka guru tersebut akan menjadi follower saja. Tinggi rendahnya self efficacy akan terlihat dari beberapa faktor yang mampu dan tidak mampu ia pengaruhi dalam lingkungan pekerjaannya dan seberapa besar ia dapat mempengaruhi lingkungan pekerjaannya tersebut.

Berbagai penelitian mengenai Self-Efficacy telah banyak dilakukan oleh para peneliti terdahulu seperti; Hubungan Antara Tingkat Self-Efficacy Guru Dengan Tingkat Burnout Pada Guru Sekolah Inklusif Di Surabaya (Puspitasari, Handayani, 2014). Dijelaskan bahwa Self-efficacy guru ialah suatu keyakinan pada kapasitas pengajaran sorang guru yang diberikan kepada siswa berupa efek positif dan menjadikan siswa sukses dalam pembelajaran. Burnout merupakan perasaan tidak berdaya, lelah, kurangnya minat yang diakibatkan oleh stres yang berkepanjangan. Hasil penelitian menunjukkan bahwa terdapat hubungan antara tingkat self-efficacy guru dengan tingkat burnout pada guru sekolah inklusif di Surabaya. Besarnya taraf signifikansi penelitian ini adalah 0,000 yang berarti terdapat hubungan yang sangat signifikan sedangkan besarnya koefisien korelasi adalah -0,662 yang berarti korelasi bersifat negatif.

Sedangkan menurut (Adirestuty, 2017) mengemukakan bahwa self-efficacy guru dan motivasi belajar pada kategori sedang. Sedangkan kreativitas guru pada kategori masih rendah. Simpulan dalam penelitian ini adalah: (1) Self-efficacy guru berpengaruh negatif terhadap motivasi belajar siswa, (2) Kreativitas guru berpengaruh positip terhadap motivasi belajar siswa, (3) Self-efficacy guru berpengaruh positip terhadap prestasi belajar siswa. Self-efficacy guru memiliki pengaruh langsung dan tidak langsung melalui motivasi belajar terhadap prestasi belajar siswa. (4) Kreativitas guru berpengaruh positip terhadap prestasi belajar siswa. Kreativitas guru memiliki pengaruh langsung dan tidak langsung melalui motivasi belajar terhadap prestasi belajar siswa. (5) Motivasi belajar siswa berpengaruh negatif terhadap prestasi belajar siswa. 

Shofiyyul Muna, Nurul Khotimah, Yeni Jamilatuz Zuhaira

DOI: https://doi.org/10.31004/edukatif.v3i5.754

Lain halnya dengan penelitian diatas, penelitian yang ditulis Hafsah, dkk. (Hafsah et al., 2020) mengenai Karakteristik self-efficacy guru matematika SMP di Kota Serang terdapat dua tipe Karakteristik selfefficacy yaitu: 1) Tipe konstruktif dan 2) Tipe normatif. Guru dengan tipe konstruktif mengembangkan kemampuannya pada setiap proses pembelajaran matematika agar tercapainya kesuksesan mengajar. Sedangkan guru dengan tipe normatif menjalankan rutinitas mengajar pada setiap proses pembelajaran matematika. Kemudian, dalam kajian yang di tulis Lantik, (Lantik, 2016) bahwa ada hubungan erat antara kinerja profesional guru dan self-efficacy guru. Oleh karena itu, kinerja profesional guru perlu terus ditingkatkan sehingga self-efficacy guru pun meningkat. Jika keduanya terjaga dan seimbang maka kualitas kerja dan pelayanan guru dapat lebih optimal. Hasil penelitian menunjukkan bahwa kinerja profesional guru fisika lulusan S-1 pendidikan fisika yang mengajar di SMA se-Kota Kupang berkategori baik, dengan perolehan nilai 3,77 dalam skala-5. Sedangkan self-efficacy guru fisika lulusan S-1 pendidikan fisika yang mengajar di SMA se-Kota Kupang berkategori tinggi, dengan perolehan nilai 3,97 dalam skala-5.

Selanjutnya, menurut Putri dan Fakhrudiana (Putri \& Fakhruddiana, 2019) Dalam penelitiannya terdapat dua subjek yang bertujuan untuk mengetahui dinamika dan faktor-faktor self-efficacy guru kelas dalam membimbing siswa slow learner. Hasil penelitian menunjukkan bahwa Subjek I telah memenuhi ketiga aspek self-efficacy dari teori Bandura (1997) dalam membimbing siswa slow learner. Yaitu; memiliki keyakinan dalam membimbing siswa slow learner, menanamkan keyakinan bahwa siswa slow learner memiliki potensi yang mampu berkembang, memiliki banyak ide dan inovasi dalam mengatasi kelambanan siswa slow learner. Sedangkan faktor yang mempengaruhi self-efficacy adalah pengalaman keberhasilan terdahulu, pengalaman orang lain, persuasi verbal, kondisi fisik dan afeksi, serta faktor berupa kondisi lingkungan sekitar. Sedangkan Untuk Subjek II, ditemukan bahwa subjek memiliki rasa pesimis dalam menghadapi siswa slow learner. Subjek II merasa kesulitan ketika menghadapi siswa slow learner, sehingga tidak banyak cara yang dilakukannya dalam menghadapi siswa slow learner. Adapun Faktor yang mempengaruhi self-efficacy Subjek II hampir sama dengan Subjek I yakni self-efficacy subjek dipengaruhi oleh pengalaman keberhasilan terdahulu, pengalaman orang lain, persuasi verbal dan kondisi fisik dan afeksi.

Dari beberapa literatur kajian pustaka yang telah dipaparkan diatas, maka penulis memfokuskan kajiannya untuk mengungkap dan mendeskripsikan Bagaimana Self-Efficacy Guru terhadap dinamika Pembelajaran online di masa pandemi Covid-19 sekarang ini.

\section{METODE PENELITIAN}

Penelitian ini menggunakan metode kualitatif. Creswell (Creswell, 2019, p. 45) mengemukakan bahwa penelitian kualitatif adalah jenis penelitian yang mengeskplorasi dan memahami makna sejumlah individu atau kelompok yang berasal dari masalah sosial.

Jenis penelitian kualitatif ini menggunakan pendekatan fenomenologi. Menurut Creswell (Creswell, 2019, p. 450) Pendekatan fenomenologi berhubungan dengan pemahaman tentang kehidupan sehari-hari dan dunia intersubyektif dari partisipan. Penelitian ini dilakukan di SD Negeri Trimulyo II, Desa Trimulyo, Kecamatan Guntur, Kabupaten Demak. Partisipan dalam penelitian ini adalah Guru SD Negeri Trimulyo II.

Teknik pengumpulan data yang diperoleh menggunakan metode wawancara. Kemudian Prosedur dalam penelitian ini yaitu: mengidentifikasi masalah, merumuskan dan membatasi masalah, melakukan studi kepustakaan, merumuskan pertanyaan penelitian, menentukan desain dan metode penelitian, menyusun instrumen dan mengumpulkan data, menganalisis data dan menyajikan hasil, menginterpretasikan temuan, serta membuat kesimpulan dan saran.

Analisis data kualitatif adalah upaya yang dilakukan dengan jalan bekerja dengan data, mengorganisasikan data, memilah-milah data sehingga menjadi satuan yang dapat dikelola guna mencari dan menemukan suatu pola dalam penelitian (Creswell, 2019, p. 271). Langkah dari analisis data penelitian ini adalah mengumpulkan data yang ada, menyusun secara sistematis, kemudian mempresentasikan hasil 
3117 Self-Efficacy Guru terhadap Dinamika Pembelajaran Online di Masa Pandemi Covid-19 - Muhammad Shofiyyul Muna, Nurul Khotimah, Yeni Jamilatuz Zuhaira

DOI: https://doi.org/10.31004/edukatif.v3i5.754

penelitian (Creswell, 2019, p. 274). Adapun data pendukung lain bersumber dari artikel jurnal, buku, dan lainlain.

\section{HASIL DAN PEMBAHASAN PENELITIAN}

Hasil dalam penelitian ini secara deskriptif dapat dijelaskan bahwa Self Efficacy merupakan konstruk yang diajukan Bandura berdasarkan Social Cognitive Theory yang dikemukakan oleh Albert Bandura pada tahun 1977. Self Efficacy atau efikasi diri memiliki konsep yang dikembangkan oleh Albert Bandura, Bandura menjelaskan keyakinan ini sebagai penentu bagaimana orang berfikir, berprilaku dan merasa (Bandura, 1997, p. 5)

Menurut Alwisol (Alwisol, 2019, pp. 287-288) Self-efficacy berbeda dengan aspirasi (cita-cita), karena cita-cita menggambarkan sesuatu ideal yang seharusnya dapat dicapai. Sedangkan Self-efficacy menggambarkan penilaian kemampuan diri. Self efficacy juga salah satu bagian pengetahuan mengenai diri yang berpengaruh terhadap kehidupan manusia (Syarifah et al., 2018) Self-efficacy guru menentukan jenis perilaku pengatasan dan seberapa besar usaha yang akan dilakukan oleh guru dalam mengatasi persoalan atau menyelesaikan tugas dan seberapa lama guru akan tetap bertahan dalam menghadapi hambatan atau pengalaman yang tidak diinginkan.

Jadi, self-efficacy adalah keyakinan individu dalam menghadapi dan menyelesaikan permasalahan yang dihadapinya diberbagai situasi serta mampu menentukan tindakan dalam menyelesaikan tugas atau masalah tertentu. Sehingga individu tersebut mampu mengatasi rintangan dan mencapai tujuan yang diharapkan.

Keyakinan diri seseorang mengenai kemampuan atau kecakapannya untuk melakukan tugas akademik yang diberikan disebut efikasi diri akademik. Bandura (Taylor, S.E. Peplau, L.T. Sears, D.O, 2009) mengemukakan bahwa peran efikasi diri sebagai mekanisme yang mendasari perubahan perilaku, pemeliharaan dan generalisasi. Perubahan perilaku terjadi setelah ada kegiatan pembelajaran siswa. Pada awal kegiatan pembelajaran, masing-masing guru mempunyai tingkat keyakinan dan kemampuan yang berbeda. Perbedaan tingkat keyakinan tersebut berdasarkan pengalaman sebelumnya misalnya penyampaian materi pelajaran yang diberikan sebelumnya, tingkat kecerdasan dan sikapnya dalam me-manage kegiatan pembelajaran baik didalam kelas maupun diluar kelas. Kemudian guru yang mempunyai efikasi diri yang baik akan berhasil dalam proses kegiatan belajar mengajarnya serta dapat melaksanakan tugas-tugas akademiknya dengan lancer (Yuliyani et al., 2017).

Kemudian Bandura (Bandura, 1997, pp. 42-43) membagi dimensi self-efficacy menjadi tiga bagian, yaitu; 1) Dimensi level atau magnitude. Dimensi ini berkaitan dengan tingkat kesulitan tugas yang diyakini oleh seseorang untuk dapat diselesaikan. Jika individu dihadapkan pada masalah atau tugas-tugas yang disusun menurut tingkat kesulitan tertentu maka self-efficacy nya akan jatuh pada tugas-tugas yang mudah, sedang, dan sulit sesuai dengan batas kemampuan yang dirasakan untuk memenuhi tuntutan perilaku yang dibutuhkan bagi masing-masing tingkatnya tersebut. Dimensi kesulitan memiliki implikasi terhadap pemilihan tingkah laku yang dicoba atau yang akan dihindari. Individu akan mencoba tingkah laku yang dirasa mampu dilakukan dan akan menghindari tingkah laku yang dirasa berada di luar batas kemampuannya. 2) Dimensi Generality. Dimensi ini merupakan dimensi yang berkaitan dengan keluasan bidang tugas yang dilakukan. Dalam mengatasi atau menyelesaikan masalah/tugas-tugasnya, beberapa individu memiliki keyakinan terbatas pada suatu aktivitas dan situasi tertentu dan beberapa menyebar pada serangkaian aktivitas dan situasi yang bervariasi. 3) Dimensi Strenght. Dimensi ini berkaitan dengan tingkat kekuatan atau kelemahan keyakinan individu tentang kemampuan yang dimilikinya. Individu dengan self-efficacy kuat mengenai kemampuannya cenderung pantang menyerah dan ulet dalam meningkatkan usahanya walaupun menghadapi rintangan. Sebaliknya individu dengan Self-Efficacy lemah cenderung mudah terguncang oleh hambatan kecil dalam menyelesaikan tugasnya. 
3118 Self-Efficacy Guru terhadap Dinamika Pembelajaran Online di Masa Pandemi Covid-19-Muhammad Shofiyyul Muna, Nurul Khotimah, Yeni Jamilatuz Zuhaira

DOI: https://doi.org/10.31004/edukatif.v3i5.754

Selain dimensi Self-Efficacy. Menurut Bandura (Bandura, 1997, pp. 80-115) yang menyatakan bahwa terdapat juga faktor-faktor yang mempengaruhi Self-Efficacy seseorang yaitu: 1) Pengalaman keberhasilan seseorang dalam menghadapi tugas tertentu pada waktu sebelumnya. Apabila seseorang pernah mengalami keberhasilan dimasa lalu maka semakin tinggi pula self-efficacy, sebaliknya apabila seseorang mengalami kegagalan dimasa lalu maka semakin rendah pula self-efficacy orang tersebut. Untuk terbentuknya efikasi diri, orang harus pernah mengalami tantangan yang berat, sehingga ia bisa menyelesaikannya dengan kegigihan dan kerja keras (Bandura, 1997). Perkembangan efikasi diri disamping ditentukan oleh keberhasilan dan kegagalan yang telah dilakukan juga ditentukan oleh kesalahan dalam menilai diri (Mukhid, 2010, p. 112). 2) Pengalaman orang lain. Individu yang melihat orang lain berhasil dalam melakukan aktifitas yang sama dan memiliki kemampuan yang sebanding dapat meningkatkan self-efficacy nya, sebaliknya jika orang yang dilihat gagal maka self-efficacy individu tersebut menurun. 3) Persuasi verbal, yaitu informasi tentang kemampuan seseorang yang disampaikan secara verbal oleh orang yang berpengaruh sehingga dapat meningkatkan keyakinan bahwa kemampuan-kemampuan yang dimiliki dapat membantu untuk mencapai apa yang diinginkan. Dorongan semangat yang diberikan kepada orang yang mempunyai potensi dan terbuka menerima informasi akan menggugah semangat orang bersangkutan untuk berusaha lebih gigih meningkatkan efikasi dirinya. Semakin percaya orang kepada kemampuan pemberi informasi maka akan semakin kuat keyakinan untuk dapat merubah efikasi diri (Rustika, 2012, p. 25). 4) Kondisi fisiologis yaitu keadaan fisik (sakit, rasa lelah dan lain-lain) dan kondisi emosional (suasana hati, stress dan lain-lain). Keadaan yang menekan tersebut dapat mempengaruhi keyakinan Akan kemampuan dirinya dalam menghadapi tugas. Jika ada hal negatif, seperti lelah, kurang sehat, cemas, atau tertekan, Akan mengurangi tingkat self-efficacy seseorang. Sebaliknya, jika seseorang dalam kondisi prima, hal ini Akan berkontribusi positif bagi perkembangan self-efficacy.

Secara psikologis, persepsi tentang kemampuan diri akan memengaruhi pikiran, perasaan, dan tindakan. Menurut (Bandura, 1997), self-efficacy yang terbentuk cenderung akan menetap dan tidak mudah berubah. Kekuatan self-efficacy Akan menjadi penentu perilaku.

Berikut ini diuraikan beberapa peranan dari terciptanya self-efficacy menurut (Lianto, 2019, pp. 58-59). Pertama, menentukan pemilihan perilaku yaitu individu cenderung memilih melakukan tugas dimana ia merasa memiliki kemampuan yang lebih tinggi untuk menjalankannya, alih-alih tugas lainnya. Hal ini menunjukkan bahwa self-efficacy menjadi pemicu munculnya suatu perilaku. Kedua, menentukan besarnya upaya dan daya juang terhadap hambatan. Menurut (Bandura, 1997), self-efficacy menentukan kekuatan dan daya tahan individu dalam mengatasi hambatan dan situasi yang tidak menyenangkan. Self-efficacy yang tinggi akan menurunkan kecemasan tentang kemampuan menyelesaikan tugas sehingga individu akan lebih tabah ketika mengalami hambatan dalam menjalankan tugasnya. Upayanya pun akan lebih banyak dikerahkan karena keyakinan bahwa usahanya tidak akan sia-sia.

Kemudian peranan ketiga, menentukan cara pikir dan reaksi emosional yaitu individu dengan selfefficacy yang rendah cenderung menganggap dirinya tidak Akan mampu menghadapi tantangan pekerjaannya. Dalam menjalankan tugasnya, mereka cenderung membesar-besarkan masalah yang akan timbul jauh lebih berat daripada kenyataannya. Mereka lebih sering merasa pesimis, mudah putus asa, dan tertekan. Sebaliknya, orang dengan self-efficacy yang tinggi akan menganggap tugas-tugas beratnya sebagai tantangan yang menarik untuk diatasi. Pikiran dan perasaannya lebih terbuka untuk menemukan solusi bagi permasalahan yang dihadapi. Keempat, prediksi perilaku yang akan muncul, yaitu orang dengan self-efficacy yang tinggi cenderung lebih berminat melibatkan diri dalam aktivitas organisasi. Interaksinya dengan lingkungan kerja lebih intensif. Dalam kerja team, mereka lebih kreatif menemukan berbagai solusi dan ikhlas bekerja keras karena keyakinan yang tinggi tentang kemampuannya. Sebaliknya individu dengan self-efficacy yang rendah cenderung lebih tertutup dan kurang terlibat dalam kerjasama team karena persepsi mereka tentang masalah dan kesulitan lebih besar ketimbang peluang untuk merubah keadaan). 
3119 Self-Efficacy Guru terhadap Dinamika Pembelajaran Online di Masa Pandemi Covid-19 - Muhammad Shofiyyul Muna, Nurul Khotimah, Yeni Jamilatuz Zuhaira

DOI: https://doi.org/10.31004/edukatif.v3i5.754

Kondisi mengenai fisik dan psikis seorang guru sangatlah penting, terutama kondisi psikisnya. Jangan sampai psikis guru tersebut terganggu, misalnya ada gangguan kecemasan yang membuat guru tersebut menjadikan self efficacy-nya menjadi rendah. Sigmud Freud dalam (Alwisol, 2019, pp. 22-23) mengemukakan tiga jenis kecemasan, yaitu: pertama, kecemasan realistik (realistic anxiety) adalah takut kepada bahaya yang nyata ada di dunia luar. Kecemasan realistik ini menjadi asal-muasal timbulnya kecemasan neurotik dan kecemasan moral. Kedua, kecemasan neurotik (neurotic anxiety), kecemasan neurotik adalah ketakutan terhadap hukuman yang bakal diterima dari orang tua atau figur penguasa lainnya, kalau seseorang tersebut berkhayal dengan caranya sendiri apa yang diyakininya akan menuai hukuman. Hukuman belum tentu diterimanya, karena orang tua belum tentu mengetahui pelanggaran yang dilakukannya, dan misalnya orang tua mengetahui juga belum tentu menjatuhkan hukuman. Jadi, hukuman dan figur pemberi hukuman dalam kecemasan neurotik bersifat khayalan. Kecemasan timbul karena orang tersebut pernah melakukan hal yang sama sewaktu masih anak-anak dan mendapat hukuman (realistik) yang dicemaskannya. Ketiga, kecemasan moral (moral anxiety). Kecemasan moral timbul ketika orang melanggar standar nilai orang tua. Kecemasan moral dan kecemasan neurotik tampak mirip, tetapi memiliki perbedaan prinsip yakni: tingkat kontrol ego. Pada kecemasan moral orang tetap rasional dalam memikirkan masalahnya berkat energi superego, sedang pada kecemasan neurotik orang dalam keadaan distres terkadang panik sehingga mereka tidak dapat berfikir jelas dan energi id menghambat penderita kecemasan neurotik membedakan antara khayalan dengan realita.

Oleh sebab itu, Berdasarkan uraian hasil diatas, maka pembahasan dalam penelitian ini Akan difokuskan dan membatasi kajian pada dimensi-dimensi self efficacy yang telah dikemukakan oleh Bandura yaitu; dimensi level atau magnitude, dimensi generality, dimensi strength. Dimensi self-efficacy dapat digunakan sebagai dasar bagi pengukuran terhadap self-efficacy Guru di SDN Trimulyo II. Adapun Subyek penelitian yang terdiri dari 11 Guru, Putra 7 dan Putri 4 diberikan Wawancara dengan keseluruhan ada 10 item pernyataan.

Pernyataan 1 sampai 3 merupakan pernyataan dimensi magnitude yang berkaitan dengan tingkat (level) kesulitan tugas yang dihadapi. Berdasarkan wawancara yang dilakukan, pada dimensi ini, guru harus dapat memperbaiki atau meningkatkan self-efficacy belief dengan mencari kondisi yang mana dapat menambahkan tantangan dan kesulitan yang lebih tinggi levelnya.

Kemudian Pernyataan 4 sampai dengan 6 mengenai dimensi generality yang merupakan perasaan kemampuan yang ditunjukkan guru pada konteks tugas yang berbeda-beda. Dalam dimensi ini, guru mungkin Akan menilai dirinya merasa yakin melalui bermacam-macam aktivitas atau hanya dalam daerah fungsi tertentu. Keadaan yang umum dan bervariasi yang di alami guru dalam jumlah dari dimensi yang berbedabeda, diantaranya tingkat kesamaan aktivitas, perasaan dimana kemampuan ditunjukkan (tingkah laku, kognitif, afektif), kemudian ciri kualitas situasi, dan karakteristik guru tersebut menuju kepada peserta didiknya.

Sisanya yaitu pernyataan 4 mencakup dimensi strength yang merupakan kuatnya keyakinan individu berkenaan dengan kemampuan yang dimiliki. Hal ini menunjukkan bahwa guru yang memiliki self-efficacy lemah dapat dengan mudah ditiadakan dengan pengalaman menggelisahkan ketika menghadapi sebuah tugas. Dengan kata lain guru merasa tidak yakin dalam menghadapi keadaan yang dialami. Namun sebaliknya, guru yang memiliki keyakinan kuat Akan tekun dan ulet pada usahanya meskipun pada tantangan dan rintangan yang tak pernah di sangka sebelumnya. Serta rata-rata guru tidak mudah dilanda kemalangan dalam melakukan sesuatu. Hal-hal diatas seperti yang dijelaskan dalam penelitian Sunaryo (Sunaryo, 2017), yang menyatakan bahwa Interpretasi self-efficacy selain dalam kriteria positif dan negatif dapat juga disajikan dalam kriteria tinggi, sedang, rendah.

Lalu, bahasan mengenai dinamika Pembelajaran Online. Menurut hasil pengamatan dalam wawancara peneliti, bahwa terdapat beberapa dinamika dalam proses pembelajaran online saat ini yaitu; Kondisi 
3120 Self-Efficacy Guru terhadap Dinamika Pembelajaran Online di Masa Pandemi Covid-19 - Muhammad Shofiyyul Muna, Nurul Khotimah, Yeni Jamilatuz Zuhaira

DOI: https://doi.org/10.31004/edukatif.v3i5.754

Pembelajaran, Metode Pembelajaran, Hasil Pembelajaran. Selain itu, aspek lain yang dapat mempengaruhi dinamika pembelajaran seperti kepemimpinan kepala sekolah, ketersediaan sarana dan prasarana serta ketersediaan guru yang profesional di bidangnya. Tentu hal-hal tersebut sangat mempengaruhi pada aspek kognitif, psikomotorik dan afektif peserta didik yang berkembang dengan lamban.

Sejalan dengan pernyataan penulis, terkait dengan dinamika pembelajaran online. Menurut (Mansyur, 2020b) dalam tulisannya menjelasakan bahwa Pembelajaran online selama pandemi tidak selamanya berjalan dengan baik dan sesuai rencana yang telah disusun. Tujuan pembelajaran tidak selamanya dicapai secara maksimal karena dinamika pembelajaran online dapat dipengaruhi oleh banyak faktor, diantaranya; Sekolah dialihkan ke rumah melalui proses pembelajaran daring. Terjadi transformasi media pembelajaran berbasis teknologi melalui penggunaan Wathshap Group, Zoom, Google Classroom, WebEx, Youtube, dan saluran TV. Penyesuaian metode pembelajaran. Penyesuaian evaluasi pembelajaran untuk penentuan standar kenaikan kelas dan kelulusan. Dan tuntutan kolaborasi orangtua peserta didik di rumah sebagai pengganti guru mengontrol pembelajaran anak.

Selanjutnya, Berdasarkan hasil wawancara penelitian, maka pembahasan dalam penelitian ini dapat di jelaskan bahwa keyakinan guru terhadap indikator/dimensi self-efficacy dapat mempengaruhi banyak aspek dalam kehidupan sehari-hari. Mengenai hal ini, guru yang memiliki self-efficacy rendah Akan merasa tak berdaya dalam menghadapi dinamika pembelajaran online. Karena guru berpikir kalau dirinya hanya punya kemungkinan kecil untuk dapat mempengaruhi situasi pembelajaran di tengah pandemi seperti ini. Rata-rata guru mempunyai keyakinan bahwa tidak ada yang bisa dilakukan untuk membuat suatu perbedaan dan Guru hanya punya sedikit kontrol dalam menjalani tugasnya.

Sedangkan guru yang memiliki self-efficacy tinggi cenderung mendapatkan nilai yang lebih baik, mempertimbangkan lebih banyak kemungkinan dalam proses pembelajaran online, memiliki banyak inovasi sehingga mendapatkan kesuksesan dalam membimbing belajar selama pandemi, dan mampu menetapkan arah tujuan dalam pembelajaran online, serta memiliki kesehatan fisik dan mental yang lebih kuat. Sesuai dari makna efikasi diri sendiri yaitu keyakinan seseorang bahwa ia memiliki kemampuan untuk mengelola dan melakukan suatu tindakan tertentu (Dewanto, 2018). Dengan kata lain, self-efficacy adalah keyakinan seseorang tentang kemampuannya untuk berhasil dalam situasi tertentu, selain itu Keyakinan atas kemampuannya menjalankan tuntutan menantang dirinya (Alfinuha \& Nuqul, 2017). Selain itu juga berkontribusi memberikan manfaat terhadap tingkat motivasi dan pencapaian kinerja (Sutarto et al., 2019).

Akan tetapi, pada umumnya seorang laki-laki memiliki self-efficacy yang lebih tinggi dari pada perempuan. Karena tampak jelas yaitu; rata-rata guru laki-laki merasa lebih yakin dan mampu menuntun kepada pengaruh-pengaruh yang positif hampir dalam semua aspek kehidupan, baik di lingkungan sekolah maupun masyarakat.

Menurut hasil diskusi yang telah dilakukan peneliti, maka dapat disimpulkan bahwa secara keseluruhan self-efficacy guru di SD Negeri Trimulyo II rata-rata berada pada level sedang dan positif. Pada dimensi magnitude rata-rata guru terlihat berada di level sedang dan positif. Hal ini menggambarkan bahwa guru akan cukup berupaya melakukan tugas yang dianggap dapat dilaksanakan dan menghindari situasi dan perilaku yang di luar batas kemampuannya. Kemudian pada dimensi generality guru berada di level sedang dan negatif. Artinya keyakinan guru untuk menyelesaikan tugas yang berbeda-beda berada di level sedang. Selain itu, guru tidak pesimis tetapi juga tidak optimis. Cukup berusaha menyelesaikan tugas yang berbeda-beda tanpa mencari strategi untuk menyelesaikannya dengan baik. Selanjutnya, dimensi terakhir yaitu strength yang juga sama berada di level sedang dan positif. Hal ini menunjukkan bahwa guru memiliki pengharapan yang cukup kuat dan mantap sehingga guru terdorong cukup gigih dalam berupaya menyelesaikan tugas dengan baik sekalipun dengan berbagai keterbatasan dalam pembelajaran online serta kurangnya pengalaman yang menunjang dalam kasus pembelajaran online seperti sekarang ini. 
3121 Self-Efficacy Guru terhadap Dinamika Pembelajaran Online di Masa Pandemi Covid-19 - Muhammad Shofiyyul Muna, Nurul Khotimah, Yeni Jamilatuz Zuhaira

DOI: https://doi.org/10.31004/edukatif.v3i5.754

\section{KESIMPULAN}

Guru yang memiliki self-efficacy rendah Akan merasa tak berdaya dalam menghadapi dinamika pembelajaran online. Karena guru berpikir kalau dirinya hanya punya kemungkinan kecil untuk dapat mempengaruhi situasi pembelajaran di masa pandemi seperti ini. Sedangkan, guru yang memiliki self-efficacy tinggi, ia mampu merencanakan aktivitas pembelajaran yang inovatif, serta dapat mentoleransi situasi-kondisi pembelajaran di tengah pandemi. Hasil diskusi dalam wawancara diperoleh kesimpulan bahwa self-efficacy Guru pada SDN Trimulyo II secara keseluruhan berada pada level sedang dan positif. Begitu juga dengan ketiga dimensi self-efficacy yaitu magnitude, generality dan strength yang masing-masing berada di tingkat sedang dan positif. Hanya dimensi generality yang negatif.

Berdasarkan kesimpulan diatas, maka penulis dapat memberikan saran dan masukan yaitu, diantaranya; 1) guru harus selalu meningkatkan efikasi diri, dengan cara membantu siswa untuk berdiskusi, memberikan bimbingan dalam belajar, memahami setiap pengalaman yang dialami, memberikan dorongan dan motivasi, menunjukkan contoh-contoh keberhasilan yang orang lain telah capai, serta bagaimana siswa dapat bekerja sama secara efektif dan mengkoordinasikan peran dan tanggungjawab siswa. 2) selama pembelajaran online. Guru juga perlu meningkatkan kemandirian belajar siswa. Dan 3) Guru harus mampu menumbuhkan rasa percaya diri siswa serta mampu menciptakan suasana pembelajaran online yang kondusif bagi siswa selama masa pandemi covid-19 sekarang ini.

\section{DAFTAR PUSTAKA}

Adirestuty, F. (2017). Pengaruh Self-Efficacy Guru dan Kreativitas Guru Terhadap Motivasi Belajar Siswa dan Implikasinya Terhadap Prestasi Belajar Pada Mata Pelajaran Ekonomi. Jurnal Wahana Pendidikan, Vol. 4(No. 1), 54-67.

Aini, E. N. (2018). Pengaruh Efikasi Diri dan Persepsi terhadap Minat Menjadi Guru Ekonomi Pada Mahasiswa Program Studi Pendidikan Ekonomi 2015 UNESA. JPEKA: Jurnal Pendidikan Ekonomi, Manajemen Dan Keuangan, 2(2). https://doi.org/10.26740/jpeka.v2n2.p83-96

Alfinuha, S., \& Nuqul, F. L. (2017). Bahagia dalam Meraih Cita-cita: Kesejahteraan Subjektif Mahasiswa Teknik Arsitektur Ditinjau dari Regulasi Emosi dan Efikasi Diri. Psikohumaniora: Jurnal Penelitian Psikologi, 2(1). https://doi.org/10.21580/pjpp.v2i1.1357

Alwisol. (2019). Psikologi Kepribadian (Cetakan Pertama). UMM Press.

Bandura, A. (1997). Self-Efficacy The Exercise of Control. W.H. Freeman and Company.

Christianto, H. (2020). Penggunaan Media Internet dalam Pemenuhan Hak atas Pendidikan di Masa Pandemi Covid-19: Perspektif Hak Asasi Manusia dan Hukum Pidana. Jurnal HAM, 11(2). https://doi.org/10.30641/ham.2020.11.239-253

Creswell, J. W. (2019). Research Design: Pendekatan Metode Kualitatif, Kuantitatif, dan Campuran (Edisi 4). PUSTAKA PELAJAR.

Dewanto, A. C. (2018). Efektivitas PPL untuk Meningkatkan Efikasi Diri Mengajar pada Mahasiswa Pendidikan Matematika. Delta: Jurnal Ilmiah Pendidikan Matematika, 6(1). https://doi.org/10.31941/delta.v6i1.662

Hafsah, Syamsuri, \& Jaenudin. (2020). Karakteristik Self-Efficacy Guru Matematika SMP di Kota Serang. Jurnal Penelitian Dan Pengajaran Matematika, Volume 2(Nomor 1), 56-72.

Lantik, V. (2016). Kinerja Profesional dan Self-Efficacy Guru Fisika SMA Lulusan S-1 Pendidikan Fisika di Kupang. Jurnal Pendidikan Matematika Dan Sains, Vol. 4(No. 1), 20-31.

Lianto, L. (2019). Self-Efficacy: A Brief Literature Review. Jurnal Manajemen Motivasi, 15(2), 55-61. https://doi.org/10.29406/jmm.v15i2.1409 
3122 Self-Efficacy Guru terhadap Dinamika Pembelajaran Online di Masa Pandemi Covid-19 - Muhammad Shofiyyul Muna, Nurul Khotimah, Yeni Jamilatuz Zuhaira

DOI: https://doi.org/10.31004/edukatif.v3i5.754

Mansyur, A. R. (2020a). Dampak COVID-19 Terhadap Dinamika Pembelajaran Di Indonesia. Education and Learning Journal, 1(2). https://doi.org/10.33096/eljour.v1i2.55

Mansyur, A. R. (2020b). Dampak COVID-19 Terhadap Dinamika Pembelajaran Di Indonesia. Education and Learning Journal, Vol. 1(No. 2), 113-123.

Mukhid, Abd. (2010). Mukhid, Abd. Self-Efficacy (Prespektif Teori Kognitif Sosial dan Implikasinya terhadap Pendidikan. Tadris, Vol. 4, No. 1, 2009. Hlm,112. Tadris, 4(1), 107-122.

Puspitasari, D. A., \& Handayani, M. M. (2014). Hubungan Tingkat Self-Efficacy Guru dengan Tingkat Burnout pada Guru Sekolah Inklusif di Surabaya. Jurnal Psikologi Pendidikan dan Perkembangan, Vol. 3(No. 1), 59-68.

Putri, F. A. R., \& Fakhruddiana, F. (2019). Self-efficacy guru kelas dalam membimbing siswa slow learner. JPK (Jurnal Pendidikan Khusus), 14(1), 1-8. https://doi.org/10.21831/jpk.v14i1.25161

Rustika, I. M. (2012). Efikasi Diri: Tinjauan Teori Albert Bandura. BULETIN PSIKOLOGI, 20(1-2), 18-25.

Sukesih, S., Usman, U., Budi, S., \& Sari, D. N. A. (2020). Pengetahuan dan Sikap Mahasiswa Kesehatan tentang Pencegahan Covid-19 Di Indonesia. Jurnal Ilmu Keperawatan Dan Kebidanan, 11(2). https://doi.org/10.26751/jikk.v11i2.835

Sunaryo, Y. (2017). Pengukuran Self-Efficacy Siswa dalam Pembelajaran Matematika di MTs N 2 Ciamis. Jurnal Teori dan Riset Matematika (TEOREMA), Vol. 1(No. 2), 39-44.

Sutarto, S., Fauzi, Y. S., Indriyani, R., Sumekar RW, D. W., \& Wibowo, A. (2019). Efikasi Diri pada Kepatuhan Minum Obat Anti Tuberkulosis (OAT). Jurnal Kesehatan, 10(3). https://doi.org/10.26630/jk.v10i3.1479

Syarifah, T. J., Usodo, B., \& Riyadi, R. (2018). Higher Order Thingking (HOT) Problems to Develop Critical Thinking Ability and Student Self Efficacy in Learning Mathematics Primary Schools. Social, Humanities, and Educational Studies (SHEs): Conference Series, 1(1). https://doi.org/10.20961/shes.v1i1.23676

Unik Hanifah Salsabila, Risma Rahma Wati, Siti Masturoh, \& Anisa Nur Rohmah. (2021). Peran Teknologi Pendidikan Dalam Internalisasi Nilai-Nilai Pendidikan Islam Di Masa Pandemi. Jurnal Pendidikan Indonesia, 2(1). https://doi.org/10.36418/japendi.v2i1.71

Yuliyani, R., Handayani, S. D., \& Somawati, S. (2017). Peran Efikasi Diri (Self-Efficacy) dan Kemampuan Berpikir Positif terhadap Kemampuan Pemecahan Masalah Matematika. Formatif: Jurnal Ilmiah Pendidikan MIPA, 7(2), 130-143. https://doi.org/10.30998/formatif.v7i2.2228 